\title{
IDENTIFYING FACTORS AFFECTING INTENTION TO USE IN DISTANCE LEARNING SYSTEMS
}

\author{
Dr. Rahmi BAKI \\ ORCID: 0000-0003-0981-5006 \\ Department of Management Information Systems \\ Aksaray University \\ Aksaray, TURKEY \\ Dr. Burak BIRGOREN \\ ORCID: 0000-0002-3340-244X \\ Department of Industrial Engineering \\ Kirikkale University \\ Kirikkale, TURKEY \\ Dr. Adnan AKTEPE \\ ORCID: 0000-0001-9045-6092 \\ Department of Industrial Engineering \\ Kirikkale University \\ Kirikkale, TURKEY
}

Received: 09/05/2020 Accepted: 08/10/2020

\begin{abstract}
The use and benefit of Distance Learning Systems (DLS) can be increased by a detailed analysis of the factors affecting students' intention to use. This study aims to analyse the effect of various independent variables on the user satisfaction and intention to use DLS via Perceived Ease of Use and Perceived Usefulness. In addition, Time Effectiveness is proposed as a new variable with the claim that the time spent in DLS is valuable. Data were collected from 925 undergraduate students currently enrolled in 9 state universities in Turkey. Data were analysed through Structural Equation Modelling (SEM). Results show that while Interaction, Compatibility and Time Effectiveness have a positive effect on user satisfaction and intention to use via Perceived Usefulness; Self Efficacy, Subjective Norm and Enjoyment have no influence. Moreover, Self Efficacy, Interaction, Anxiety and Time Effectiveness have a significant impact on Perceived Ease of Use, yet Subjective Norm and Enjoyment don't.
\end{abstract}

Keywords: Distance Learning System, Technology Acceptance Model, intention to use, user satisfaction, e-learning.

\section{INTRODUCTION}

Rapid developments in information and communications technologies have caused massive shifts in every aspect of life, including education, which paved the way for the emergence of Distance Learning Systems (DLS). DLS provide unique opportunities to cater for the ever-increasing needs of the modern education system via facilitating learning without time and location constraints (Chen, Wei, \& Chen, 2008). Nevertheless, functions and operations of DLS are more complicated than conventional technologies (Liao, 2006) and their operating and maintenance expenditures can create financial burdens for educational institutions. Therefore, analysis and identification of factors influencing DLS performance is a strategic research topic. 
Researchers have made use of various theories such as Technology Acceptance Model, Task-Technology Fit Theory, Theory of Planned Behaviour and Three-Tier Use Model in order to explain distance learning' acceptance. Among these, Technology Acceptance Model is the most frequently used theory (Sumak, Hericko, \& Pusnik, 2011). It is a theoretically and empirically validated, influential theory that aims to clarify users' technology adoption (Heijden, 2003). This theory argues that the intention to use information technologies is triggered by two belief (Perceived Ease of Use and Perceived Usefulness) variables (Davis, Bagozzi, \& Warshaw, 1989). Perceived Ease of Use is the degree that a user has faith in the belief that he/she will not make an extra effort during the use of technology. Perceived Usefulness is the degree to which a user has faith in the belief that the use of technology will improve work performance (Venkatesh \& Bala, 2008). Numerous studies have examined the relationship between independent variables and system usage through belief structures. This study starts with a detailed literature review to identify the variables and hypotheses that are most frequently found to have significant impact on Perceived Ease of Use and Perceived Usefulness of DLS' acceptance. The extended model which these variables and hypotheses are added is tested on DLS users.

In order to shed light on the untested issues prevalent in the literature, a new variable to the model is proposed. A large majority of students studying at tertiary level institutions belong to the $\mathrm{Z}$ generation, a term given to those born after 2000. This generation regards technology as a part of life, lives fast, thinks in a target-oriented way, has a relatively shorter attention span and their acceptance of DLS depends on the positive correlation between the time spent on the system and the rewards it brings. Therefore, a new variable called Time Effectiveness is introduced, which questions whether spending time on the system is worth it. One of Technology Acceptance Model's belief variables, Perceived Usefulness, focuses on whether the system improves work performance or not, while Perceived Ease of Use pays attention to whether the use of the system requires any considerable effort. As Time Effectiveness focuses on whether the user thinks the time spent is used efficiently, this study tests the impact of Time Effectiveness on the aforementioned belief variables.

Although many models related to information systems have Satisfaction variable (Al-Azawei \& Lundqvist, 2015, Al-Azawei, Parslow, \& Lundqvist, 2017, Al-Hawari \& Mouakket, 2010, De Lone \& Mc Lean, 1992, Joo, So, \& Kim, 2018), this variable does not exist in the Technology Acceptance Model. In order to assess the factors that explain the user contentment in DLS, the variable Satisfaction which is defined as 'a measure of pleasant feeling when expectations of customers are met at desired levels with provided services' is also included in the model. In the literature, studies investigating the acceptance of distance learning through the Technology Acceptance Model, using the Satisfaction variable, have been examined. Based on the results of these studies, Satisfaction variable was added to the proposed model.

The study aims to;

(i) identify and test the frequently accepted hypotheses in the literature

(ii) propose the Time Effectiveness variable into the Technology Acceptance Model and determine its effect on belief variables,

(iii) incorporate Satisfaction as an explanatory variable into the Technology Acceptance Model and assess its inter-correlation via the independent variables of the model,

(iv) shed light on the factors that influence DLS acceptance of Turkish university students and

(v) providing guidance for studies aimed at expanding the use of DLS. The model proposed in this study has the advantage of bridging the gap in DLS acceptance studies. An integrated approach, in which the most accepted variables in the literature are used, is developed with the Time Effectiveness and Satisfaction variables.

The rest of the paper is organized as follows: First, brief information regarding the frequently tested hypotheses in the current literature and the justification for doing so is given. Then, steps taken to adapt the scale items, the data collection and analyses processes are presented in detail. Then, the results of the tests are set forth and their implications are scrutinized. In the end, implications of these empirical tests are evaluated, limitations of the study are discussed and potential research questions are put forward. 


\section{Literature Search and Proposed Hypotheses}

Low acceptance rate in information technologies is the biggest obstacle to system success. In the literature, researchers have used numerous theories to explain users' DLS acceptance. The Technology Acceptance Model (Figure 1) is the most frequently used theory in the literature (Sumak et al., 2011). Technology Acceptance Model is a theoretically and empirically validated, influential model aiming to clarify users' technology adoption (Heijden, 2003). According to the theory, a person's use of a system is identified by the two belief variables Perceived Ease of Use and Perceived Usefulness. Perceived Ease of Use is the degree that a user has faith in the belief that he/she will not make an extra effort during the use of technology. Perceived Usefulness is the degree to which a user has faith in the belief that the use of technology will improve work performance (Venkatesh \& Bala, 2008).

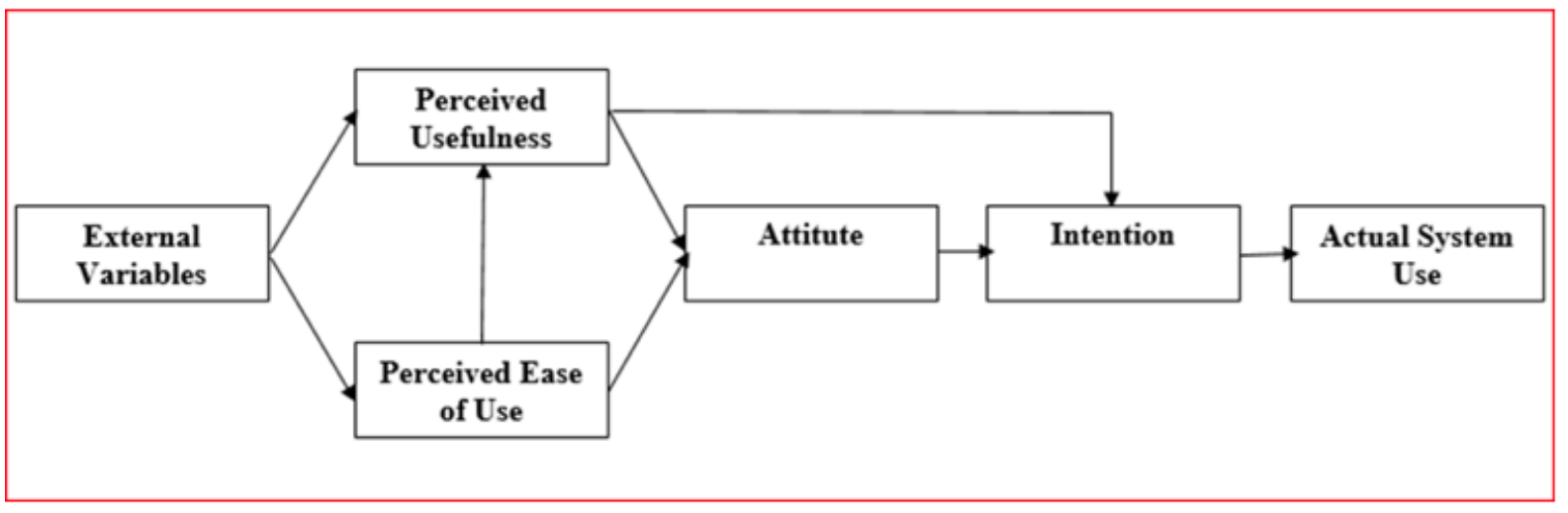

Figure 1. Technology Acceptance Model

External variables are known as antecedents of belief variables and have a strategic role in determining technology acceptance behaviours (Abdullah \& Ward, 2016). Incorporating these external factors into the model helps explaining system usage, since they facilitate a better understanding of belief variables and their triggering forces (Legris, Ingham, \& Collerette, 2003). The main target of Technology Acceptance Model is to establish a base for observing the influence of external variables on belief and intention (Davis et al., 1989). For this reason, many researchers have expanded and tested model with different external variables. For instance, Technology Acceptance Model 2 incorporates the antecedents of Perceived Usefulness (Venkatesh \& Davis, 2000) and by including the explanatory variables deemed to influence Perceived Ease of Use, Technology Acceptance Model 3 is structured (Venkatesh \& Bala, 2008). Extending and testing the Technology Acceptance Model with social and personal variables in DLS acceptance studies will contribute to the spread of the system.

This study assesses the explanatory power of seven independent variables (Self Efficacy, Subjective Norm, Interaction, Enjoyment, Compatibility, Anxiety and Time Effectiveness) on user satisfaction and intention to use through belief structures. Hypotheses proposed in the model are determined after a systematic and thorough literature review. Table 1 lists the studies that accept those hypotheses.

The reviewed researches were identified after a careful assessment of Google Scholar, Science Direct, ProQuest Dissertations \& Thesis Global, EBSCOhost and Taylor \& Frances databases. Criteria taken into consideration upon this identification are listed as follows:

(i) Studies should focus on usage or acceptance of distance learning technologies or systems,

(ii) Models proposed in those studies should at least include one of the belief structures (Perceived Usefulness and Perceived Ease of Use),

(iii) Studies should test at least one explanatory variable's effect on belief structures,

(iv) The model proposed in the study should be empirically tested and the results should be clearly communicated. Rationales behind hypotheses selected from literature review can be described as follows; 
Table 1. Proposed Hypotheses are Accepted in Distance Learning Literature (External Variables $\rightarrow$ Belief Variables)

\begin{tabular}{|c|c|c|}
\hline & Hypothesis & Studies in which the hypothesis is accepted \\
\hline $\mathrm{H} 1$ & $\begin{array}{l}\text { Self Efficacy } \rightarrow \text { Perceived } \\
\text { Usefulness }\end{array}$ & $\begin{array}{l}\text { Al-Ammari \& Hamad, 2008, Al-Ammary et al., 2014, Al-Azawei \& Lundqvist, 2015, Al- } \\
\text { Azawei et al., 2017, Al-Mushasha, 2013, Althunibat, 2015, Aypay et al., 2012, Chen \& } \\
\text { Tseng, 2012, Chow et al., 2012, Coskuncay \& Ozkan, 2013, Hsiao \& Chen, 2015, Jung, } \\
\text { 2015, Kang \& Shin, 2015, Karaali et al., 2011, Lee et al., 2014, Lee \& Lehto, 2013, Nagy, } \\
\text { 2018, Ong \& Lai, 2006, Ong et al., 2004, Park, 2009, Song \& Kong, } 2017\end{array}$ \\
\hline $\mathrm{H} 2$ & $\begin{array}{l}\text { Self Efficacy } \rightarrow \text { Perceived } \\
\text { Ease of Use }\end{array}$ & $\begin{array}{l}\text { Abbad et al., 2009, Abdullah et al., 2016, Abramson et al., 2015, Al-Ammari \& Hamad, } \\
\text { 2008, Al-Ammary et al., 2014, Al-Azawei \& Lundqvist, 2015, Al-Azawei et al., 2017, } \\
\text { Al-Gahtani, 2016, Ali et al., 2013, Al-Mushasha 2013, Althunibat, 2015, Basoglu \& } \\
\text { Ozdogan, 2015, Bhatiasevi, 2011, Brown et al., 2006, Chang et al., 2017, Chen \& Tseng, } \\
\text { 2012, Chow et al., 2012, Chow et al., 2013, Cigdem \& Topcu, 2015, Hsia et al., 2014, } \\
\text { Hsiao \& Chen, 2015, Kilic et al., 2015, Lee, 2006, Lee et al., 2011.b, Lee et al., 2013, Li et } \\
\text { al., 2012, Lin et al., 2010, Liu, 2010, Mei et al., 2018, Moghadam \& Bairamzadeh, 2009, } \\
\text { Motaghian et al., 2013, Moreno et., 2017, Nagy et al., 2018, Ong \& Lai, 2006, Ong et al., } \\
\text { 2004, Padilla-Melendez et al., 2008, Park, 2009.a, Park et al., 2012, Pituch \& Lee, 2006, } \\
\text { Punnoose, 2012, Shen, \& Chuang, 2010, Song \& Kong, 2017, Tran, 2016, Tseng \& Hsia, } \\
\text { 2008, Wang \& Wang, 2009, Wu et al., 2013, Yalcin \& Kutlu, 2019, Yang \& Lin, 2011, Yi- } \\
\text { Cheng et al., 2007, Yuen \& Ma, } 2008\end{array}$ \\
\hline $\mathrm{H} 3$ & $\begin{array}{l}\text { Subjective } \\
\text { Norm } \rightarrow \text { Perceived } \\
\text { Usefulness }\end{array}$ & $\begin{array}{l}\text { Agudo-Peregrina et al., 2014, Al-Gahtani, 2016, Al-Sharafi et al., 2019, Chang et al., } \\
\text { 2017, Cigdem \& Topcu, 2015, Coskuncay \& Ozkan, 2013, Davis \& Wong, 2007, De Smet } \\
\text { et al., 2012, Farahat, 2012, Kang \& Shin, 2015, Karaali et al., 2011, Kimathi \& Zhang, 2019, } \\
\text { Lee, 2006, Lee et al., 2011.b, Liu \&Wei, 2019, Martin, 2012, Mei et al., 2018, Moghadam } \\
\text { \& Bairamzadeh, 2009, Motaghian et al., 2013, Olson \& Brown, 2018, Park, 2009, Park et } \\
\text { al., 2012.a, Park et al., 2012.b, Post, 2010, Punnoose, 2012, Raaij \& Schepers, 2008, Song } \\
\text { \& Kong, 2017, Wang \& Wang, 2009, Wu \& Chen, 2017, Yalcin \& Kutlu, 2019, Yang \& Lin, } \\
\text { 2011, Yuen, \& Ma, } 2008\end{array}$ \\
\hline $\mathrm{H} 4$ & $\begin{array}{l}\text { Subjective } \\
\text { Norm } \rightarrow \text { Perceived Ease } \\
\text { of Use }\end{array}$ & $\begin{array}{l}\text { Abdullah et al., 2016, Abramson et al., 2015, Cigdem \& Topcu, 2015, Coskuncay \& } \\
\text { Ozkan, 2013, Farahat, 2012, Kang \& Shin, 2015, Kimathi \& Zhang, 2019, Lee et al., } \\
\text { 2011.b, Motaghian et al., 2013, Olson \& Brown, 2018, Yuen \& Ma, } 2008\end{array}$ \\
\hline H5 & $\begin{array}{l}\text { Interaction } \rightarrow \text { Perceived } \\
\text { Usefulness }\end{array}$ & $\begin{array}{l}\text { Baharin et al., 2015, Binyamin et al., 2019, Chang et al., 2017, Cheng, 2011, Cheng, } \\
\text { 2012, Cheng, 2013, Jung, 2015, Lin et al., 2014, Martin, 2012, Martinez-Torres et al., } \\
\text { 2008, Moreno et al., 2017, Pituch \& Lee, 2006, Shen \& Chuang, } 2010\end{array}$ \\
\hline $\mathrm{H} 6$ & $\begin{array}{l}\text { Interaction } \rightarrow \text { Perceived } \\
\quad \text { Ease of Use }\end{array}$ & $\begin{array}{l}\text { Armenteros et al., 2013, Binyamin et al., 2019, Chang \& Liu, 2013, Cheng, 2011, Cheng, } \\
\text { 2012, Cheng, 2013, Li et al., 2012, Lin et al., 2014, Shen \& Chuang, } 2010\end{array}$ \\
\hline $\mathrm{H} 7$ & $\begin{array}{c}\text { Enjoyment } \rightarrow \text { Perceived } \\
\text { Usefulness }\end{array}$ & $\begin{array}{l}\text { Abdullah et al., 2016, Al-Aulamie et al., 2012, Al-Rahmi et al., 2019.a, Al-Rahmi et al., } \\
\text { 2019.b, Armenteros et al., 2013, Chang et al., 2017, Chen et al., 2013, Lai \& Ulhas, } \\
\text { 2012, Lin et al., 2010, Park et al., 2012.b, Wu \& Gao, 2011, Yi-Cheng et al., 2007, Zare \& } \\
\text { Yazdanparast, 2013, Zhang et al., } 2007\end{array}$ \\
\hline $\mathrm{H} 8$ & $\begin{array}{l}\text { Enjoyment } \rightarrow \text { Perceived } \\
\text { Ease of Use }\end{array}$ & $\begin{array}{l}\text { Abdullah et al., 2016, Al-Ammary et al., 2014, Al-Aulamie et al., 2012, Al-Gahtani, 2016, } \\
\text { Al-Rahmi et al., 2019.a, Al-Rahmi et al., 2019.b, Al-Sharafi et al., 2019, Arenas-Gaitan } \\
\text { et al., 2010, Armenteros et al., 2013, Chang et al., 2017, Chen et al., 2013, Huang et al., } \\
\text { 2007, Kimathi \& Zhang, 2019, Martinez-Torres et al., 2008, Ramirez-Correa et al., 2015, } \\
\text { Shyu \& Huang, 2011, Zare \& Yazdanparast, } 2013\end{array}$ \\
\hline $\mathrm{H} 9$ & $\begin{array}{l}\text { Compatibility } \rightarrow \text { Perceived } \\
\text { Usefulness }\end{array}$ & $\begin{array}{l}\text { Al-Rahmi et al., 2019.a, Brown et al., 2006, Chang et al., 2017, Cheng, 2015, Jung, 2015, } \\
\text { Lai \& Ulhas, 2012, Lee et al., 2011.a, Post, 2010, Purnomo \& Lee, 2013, Tung \& Chang, } \\
\text { 2008.a, Tung \& Chang, 2008.b }\end{array}$ \\
\hline $\mathrm{H} 10$ & $\begin{array}{l}\text { Anxiety } \rightarrow \text { Perceived Ease } \\
\text { of Use }\end{array}$ & $\begin{array}{l}\text { Agudo-Peregrina et al., 2014, Al-Gahtani 2016, Ali et al., 2013, Chang et al., 2017, Chen } \\
\text { \&Tseng, 2012, Calisir et al., 2014, Karaali et al., 2011, Kimathi \& Zhang, 2019, Lefievre, } \\
\text { 2012, Park et al., 2012.b, Raaij \& Schepers, 2008, Saade \& Kira, 2006, Song \& Kong, } 2017\end{array}$ \\
\hline
\end{tabular}

Self Efficacy is considered as a significant determinant of human behaviour (Bandura, 1982). From a technological perspective, Self Efficacy is the belief that one has the ability to undertake certain computer operations. This determinant is used frequently in predicting users' adoption of various information technologies applications (Hsia, Chen, Chiang, Hsu, \& Tseng, 2018). A user with high Self Efficacy is expected to find DLS easy to use. Moreover, it is likely that he/she will presume the circumvention of possible obstacles of DLS usage and expect to benefit from the system. 
Hyp. 1; Self Efficacy has an impact on Perceived Usefulness of learners that uses the DLS.

Hyp. 2; Self Efficacy has an impact on Perceived Ease of Use of learners that uses the DLS

Subjective Norm is the social pressure that people sense from their social circle during any action (Ajzen, 1991). Subjective Norm from the perspective of DLS means the social pressure that the students' sense in the use of DLS in their social circles. The social pressure on whether to use DLS or not, can affect the learner's perception that the system is beneficial and easy to use. Thus, subjective norm affects the intention to use DLS through the Perceived Usefulness and Perceived Ease of Use of users.

Hyp. 3; Subjective Norm has an impact on Perceived Usefulness of learners that uses the DLS.

Hyp. 4; Subjective Norm has an impact on Perceived Ease of Use of learners that uses the DLS.

The interaction of learners with each other and with their instructors is a strategic element of the learning process. Interaction in DLS occurs via tools such as e-mail or chat room. Students can communicate and exchange ideas with each other through forum discussion platforms or video conferencing tools. A user's perception regarding the level of advanced interaction, which can be described as the degree of belief that the DLS acts as an impetus for facilitating interaction with teachers and students, can contribute to the perceived advantageousness of the system. Moreover, it is highly likely that a user's effective and agile communication with other parties will trigger her perception regarding the ease of use.

Hyp. 5; Interaction has an impact on Perceived Usefulness of learners that uses the DLS.

Hyp. 6; Interaction has an impact on Perceived Ease of Use of learners that uses the DLS.

Enjoyment is the degree to which a technology-use activity is perceived to be fun on its own, without considering any expected performance result (Lubbe \& Louw, 2010). In the perspective of DLS, it is the degree of the belief of user that use of system is an exciting and fun activity, except for the learning output of the user. It is expected that a student, who finds the DLS enjoyable without thinking about its learning outcome, considers that she/he will able to use the system without extra effort. It is also possible that as a result of system usage, student may consider that she/he will benefit from the system.

Hyp. 7; Enjoyment has an impact on Perceived Usefulness of learners that uses the DLS.

Hyp. 8; Enjoyment has an impact on Perceived Ease of Use of learners that uses the DLS.

Compatibility is the degree of, for any innovation, potential users to comply with value judgments and requirements (Moore \& Benbasat, 1991). A greater degree of compatibility results in a faster system adoption. In the literature, compatibility is generally tested against and found out to have a significant relationship with Perceived Usefulness. A student's perception of the DLS in accordance with his/her needs, experiences and values may affect the perception that the system is beneficial for the user.

Hyp. 9; Compatibility has an impact on Perceived Usefulness of learners that uses the DLS.

Computer Anxiety is the inclination to feel uneasy and worried about the usage of computer technologies (Igbaria \& Parasuraman, 1989). An individual's anxiety regarding computers and technology is highly likely to impede her utilization of DLS or usage of any systems tool to facilitate possible learning activities. According to the conducted literature search, it was obtained that the effect of Anxiety on Perceived Ease of Use was tested mostly and had a negative effect. If a student is worried about the use of the DLS, he/she may consider the system as more complex than what it actually is, and presumes that the system is hard to use. For this reason, anxiety of students, through Perceived Ease of Use, is expected to influence negatively their intention to use the DLS.

Hyp. 10; Anxiety has an impact (negative) on Perceived Ease of Use of learners that uses the DLS.

Abdullah and Ward (2016) analyse 107 researches that investigate users' distance learning acceptance via utilizing Technology Acceptance Model, concluding that Self Efficacy, Subjective Norm, Enjoyment, Anxiety and Experience to be the most frequently used external variables in explaining this behaviour. In another study by Baki, Birgoren and Aktepe (2018), 203 papers were investigated. In their study, Self Efficacy, Subjective Norm, Interaction, Enjoyment, Compatibility and Anxiety variables were found to be the independent variables whose effects on belief variables were most frequently accepted. 
A large majority of students from higher education institutions who are born after the year 2000, called the generation $\mathrm{Z}$, in the near future. It is obvious that internet technology and digital equipment are part of everyday life for the generation $\mathrm{Z}$. However, individuals of this generation deal with more than one subject at the same time, consume quickly and easily lose their interest about events (Ozen, Altunoglu, \& Oztornaci, 2015). Compared to other generations, this generation loves speed and lives faster. Generation $Z$ consists of individuals who are target-oriented, less loyal and who emphasize flexibility (Vogel, 2015).

Considering the characteristics of the $\mathrm{Z}$ generation representatives, their acceptance of a DLS depends on not spending too much time in the system and the thought of being rewarded for the time spent on the system. In the literature review, it is observed that no variable is defined and tested in the time perspective that the users spent. In order to fill this gap, a new variable, defined as Time Effectiveness, is included as a new dimension. Time Effectiveness can be defined as the perception that users think the learning output, they gain from the system is worth the time they spend on the system. The items that measure the Time Effectiveness variable in the scale, are positive questions, indicating that users spend time efficiently when using the system (Appendix A).

Hyp. 11; Time Effectiveness has an impact on Perceived Usefulness of learners that uses the DLS.

Hyp. 12; Time Effectiveness has an impact on Perceived Ease of Use of learners that uses the DLS.

Satisfaction is a measure of nice feeling when the services assured meet the expectations of the customers at the desired level. A consumer's purchase of a product, and adoption of a technology by using it consistently, are analogous. User satisfaction is one of the significant criteria determining the effectiveness of information technologies (De Lone \& Mc Lean, 1992). Original Technology Acceptance Model does not include Satisfaction variable, which is a strategic determinant of information technologies' success. In this study, research analysing students' distance learning technology acceptance through Technology Acceptance Model is reviewed and Satisfaction is included into the proposed model (Table 2). 11 and 6 of these studies accept Perceived Usefulness and Perceived Ease of Use as positive and significant determinants of User Satisfaction, respectively. Moreover, 13 studies put forth User Satisfaction as an antecedent of Intention to Use. Therefore, User Satisfaction a variable lacking in the original Technology Acceptance Model, is introduced into the model.

Users tend to use a practice to the extent that they think they will do their task better (Davis, 1989). Perceived Usefulness is considered as a predictor of learning satisfaction (Olsen \& Brown, 2018). It is likely that, if a student using DLS thinks that the system is useful and that it will improve his or her performance, then this situation has an effect on the learner's satisfaction with the system.

Hyp. 13; Perceived Usefulness has an impact on satisfaction of learners that uses the DLS.

Table 2. The Relationships of Satisfaction Variable with Belief Variables and with Intention in Distance Education Literature

\begin{tabular}{|c|c|}
\hline Hypothesis & Studies in which the hypothesis is accepted \\
\hline \multirow{2}{*}{$\begin{array}{l}\text { Perceived } \\
\text { Usefulness } \rightarrow \text { Satisfaction } \\
\text { Perceived Ease of } \\
\text { Use } \rightarrow \text { Satisfaction }\end{array}$} & $\begin{array}{l}\text { Al-Azawei \& Lundqvist, 2015, Al-Azawei et al., 2017, Al-Hawari \& Mouakket, 2010, Joo et al., } \\
\text { 2018, Lee 2010, Lee \& Lehto, 2013, Ma et al., 2013, Olson \& Brown, 2018, Park et al., 2012.b, Roca } \\
\text { et al., 2006, Shih et al., } 2013\end{array}$ \\
\hline & $\begin{array}{l}\text { Al-Azawei et al., 2017, Joo et al., 2018, Nagy, 2018, Olson \& Brown, 2018, Park et al., 2012.b, } \\
\text { Roca et al., 2006, Shih et al., } 2013\end{array}$ \\
\hline Satisfaction $\rightarrow$ Intention & $\begin{array}{l}\text { Cheng 2019, Cho et al., 2009.a, Cho et al., 2009.b, Joo et al., 2018, Lee 2010, Lee \& Lehto, 2013, } \\
\text { Ma et al., 2013, Mohammadi 2015.a, Mohammadi 2015.b, Olson \& Brown, 2018, Ramayah \& } \\
\text { Lee, 2012, Roca et al., 2006, Shih et al., } 2013\end{array}$ \\
\hline
\end{tabular}

Even when a user believes that an application is beneficial, she or he will question the level of effort for using the application and the advantages of performance of use, if it is claimed that the system is difficult to use. Thus, together with usefulness, ease of use is also influential in the system acceptance (Davis, 1989). Perceived Ease of Use is also a direct determinant of Perceived Usefulness. The perception of a system's level of ease of use can affect the perception of system usability. Perceived Ease of Use has an effect on the intention, in two ways; directly and through the perception of the benefit. It is expected that students will be 
satisfied with a system if they perceive the use of the system as easy to use and think that they will not make an effort to force themselves when use the system. Furthermore, it is possible that the user's opinion of the system as easy or difficult may have an effect on the opinion that the system is beneficial.

Hyp. 14; Perceived Ease of Use has an impact on satisfaction of learners that uses the DLS.

Hyp. 15; Perceived Ease of Use has an impact on Perceived Usefulness of learners that uses the DLS.

Hyp. 16; Satisfaction has an impact on intention of learners that uses the DLS.

Intention variable is used as a key dependent variable in the proposed model. It is aimed to guide corrective actions that will increase intention of students to use these systems, by identifying concepts that have a powerful effect on the intention to use. The model proposed in this research is presented in Figure 2.

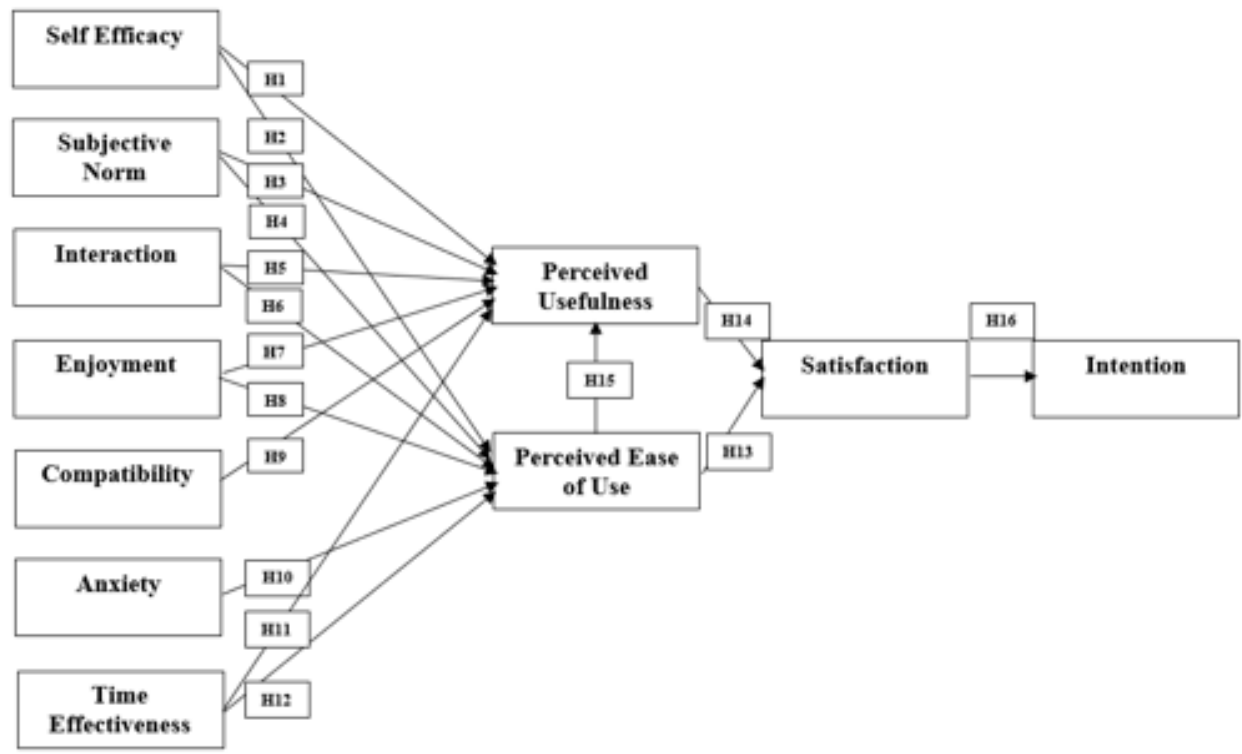

Figure 2. Hypothetical Model

\section{METHOD}

This section gives information about the preparation process of the surveys, the respondents, method used in data-and-output analysis and hypothesis results.

\section{Participants}

A survey is developed for testing the hypotheses put forward in the model. Items used in this questionnaire are collected from previous research, translated into Turkish and adapted to DLS (Appendix A). Since Time Effectiveness was not included in the models proposed in the literature review, items regarding the variable are newly developed for this study.

The developed questionnaire, firstly, was tested via a pilot program to identify the compatibility, comprehensibility and the completion period of the scale. The pilot study took place in two state universities between February and March, 2018 with 303 participants. Responses of participants that have not used DLS and incomplete / insufficient responses were eliminated and a sample size of 239 was reached. The ultimate version of the questionnaire was constructed after a thorough analysis of this pilot test.

The survey comprises two parts where the first section has 7 demographic questions and the second part contains 35 questions evaluated on a five-level Likert type scale. The main study has been conducted between April 2018 and June 2018. In order to collect data rapidly and to provide reliability, it was carried out via face to face meeting, rather than online methods. The criteria used for sample selection are as follows; participants must be a student at a state university in Turkey, they must have followed at least one distance education course for a full semester and university that the students are enrolled in must have offered some of 
their compulsory courses through its DLS. In order to obtain a comprehensive result, 9 different universities, 11 different faculties and 28 different departments were included in the study. A total of 1080 questionnaires were distributed to the learners. After omitting partially or incorrectly completed questionnaires and those filled by students who had not taken a distance education course, 925 (85,65\%) valid questionnaires remained for the analysis. Data were analysed via Structural Equation Modelling (SEM) in SPSS AMOS 20 software. The model tested in this study was estimated using maximum likelihood estimation.

Among participants, rate of females is greater than number of males $(56,4 \%)$. A large portion of the participants are between 18-21 years old (69.3\%). Freshmen students comprise the largest participating class $(37,1 \%)$. Most participants have at least 3 years of computer experience $(78,1 \%)$; however, no information is acquired regarding their experience processes on DLS (Table 3). In the current system used by the participants, there is no interaction method used for education.

\section{Data Collection and Analysis}

Data gathered were analysed via a two-step methodology that comprises of the assessment of measurement model and structural model. No revisions to the model were made during these steps. Following the evaluation of the reliability and internal consistency of the factors used in the model, the aforementioned hypotheses were tested.

The item reliability for the underlying items for each construct was measured using standardized factor loadings. The results show that the loading of all items is higher than the recommended value of 0.5 (Hair, Black, Babin, \& Anderson, 2010). The lowest three factor loadings are between 0.621 and 0.685 (Anxiety 1 0.621 , Perceived Usefulness $4-0.678$ and Perceived Ease of Use 2 - 0.685). The highest three factor loadings are between 0.950 and 0.959 (Subjective Norm 2 - 0.950, Perceived Usefulness 2 - 0.957 and Enjoyment 2 - 0.959). Items with high factor loadings are highly loaded to their underlying constructs and show higher item reliability (Table 4).

Table 3. Demographic Profiles of the Participants

\begin{tabular}{lcc}
\hline Demographic Profile $(\mathrm{n}=925)$ & Frequency & Percentage (\%) \\
\hline Gender & & \\
Female & 522 & 56.1 \\
Male & 403 & 43.6 \\
Age & & \\
$18-21$ & 641 & 69.3 \\
$22-25$ & 252 & 27.2 \\
$26<$ & 32 & 3.5 \\
Year of Study & & \\
1 & 343 & 37.1 \\
2 & 202 & 21.8 \\
3 & 252 & 27.2 \\
4 & 128 & 13.8 \\
Experience in Using Computers (Year) & & \\
$<1$ & 109 & 11.8 \\
$1-3$ & 93 & 10.1 \\
$3-6$ & 134 & 14.5 \\
$6-9$ & 215 & 13.2 \\
$9<$ & 374 & 40.4 \\
Faculties of Students & & \\
FEAS & 276 & 29.8 \\
Faculty of Engineering & 202 & 21.8 \\
Faculty of Art and Sciences & 194 & 21 \\
Faculty of Law & 81 & 8.8 \\
Faculty of Health Sciences & 61 & 6.6 \\
\hline Nit Ther is no intion
\end{tabular}

Note: There is no interaction method used for training in the current system. 
The convergent validity of the measurement model is tested via Confirmatory Factor Analysis (CFA) where the correlation among variables expected to have a relationship with underlying convergent validity. Theory suggests that Composite Reliability (CR) (Hair, Anderson, Tatham, \& Black, 1998) and Average Variance Extracted (AVE) (Fornell \& Larcker, 1981) should be higher than 0.7 and 0.5 respectively, to ensure convergent validity. Moreover, the explanatory power of Cronbach's Alpha values on internal consistency are evaluated on a six-level scale where coefficients above 0.7 are considered acceptable (George \& Mallery, 2003).

In this research, all constructs are tested for reliability and validity. Reliability test is an evaluation of the degree of consistency between multiple measurements of a variable (Hair et al., 2010). Cronbach's Alpha value is used for reliability analysis. The results showed that alpha values for all variables are above the recommended value in the literature and the scale is reliable. Based on the six cut-off points proposed by George and Mallery, Cronbach's Alpha results show that four construct has excellent reliability (Enjoyment-0.951, Compatibility-0.902, Perceived Usefulness -0.959 and Satisfaction-0.940) and seven constructs has good reliability (SelfEfficacy-0.900, Subjective Norm-0.839, Interaction-0.850, Anxiety-0.815, Time Effectiveness -0.883, Perceived Ease of Use -0.851 and Intention-0.880).

The result of the CFA on the model's proposed variables demonstrate the CR values to vary between 0.823 and 0.952 while AVE values have a range of 0.541 to 0.868 , leading to the conclusion that the CR and AVE values of all variables are above the acceptable cut-off threshold of the literature. Moreover, Cronbach's Alpha values of these variables vary between 0.815 and 0.959 , which are shown to exhibit a good level of reliability (Table 4).

Table 4. Measurement Model Outcomes of the Analysis

\begin{tabular}{|c|c|c|c|c|c|}
\hline Constructs & Item & Factor Loading & Cronbach's Alpha & CR & AVE \\
\hline \multirow[t]{3}{*}{ Self Efficacy } & 1 & 0.800 & 0.900 & 0.904 & 0.758 \\
\hline & 2 & 0.935 & & & \\
\hline & 3 & 0.872 & & & \\
\hline \multirow[t]{2}{*}{ Subjective Norm } & 1 & 0.761 & 0.839 & 0.850 & 0.741 \\
\hline & 2 & 0.950 & & & \\
\hline \multirow[t]{3}{*}{ Enjoyment } & 1 & 0.926 & 0.951 & 0.952 & 0.868 \\
\hline & 2 & 0.959 & & & \\
\hline & 3 & 0.910 & & & \\
\hline \multirow[t]{3}{*}{ Compatibility } & 1 & 0.857 & 0.902 & 0.903 & 0.755 \\
\hline & 2 & 0.861 & & & \\
\hline & 3 & 0.889 & & & \\
\hline \multirow[t]{3}{*}{ Interaction } & 1 & 0.709 & 0.850 & 0.853 & 0.662 \\
\hline & 2 & 0.853 & & & \\
\hline & 3 & 0.869 & & & \\
\hline \multirow[t]{4}{*}{ Anxiety } & 1 & 0.621 & 0.815 & 0.823 & 0.541 \\
\hline & 2 & 0.709 & & & \\
\hline & 3 & 0.840 & & & \\
\hline & 4 & 0.754 & & & \\
\hline \multirow[t]{3}{*}{ Time Effectiveness } & 1 & 0.816 & 0.883 & 0.885 & 0.719 \\
\hline & 2 & 0.849 & & & \\
\hline & 3 & 0.878 & & & \\
\hline \multirow[t]{4}{*}{ Perceived Ease of Use } & 1 & 0.719 & 0.851 & 0.857 & 0.601 \\
\hline & 2 & 0.957 & & & \\
\hline & 3 & 0.852 & & & \\
\hline & 4 & 0.832 & & & \\
\hline \multirow[t]{4}{*}{ Perceived Usefulness } & 1 & 0.937 & 0.959 & 0.933 & 0.781 \\
\hline & 2 & 0.957 & & & \\
\hline & 3 & 0.933 & & & \\
\hline & 4 & 0.678 & & & \\
\hline \multirow[t]{3}{*}{ Intention } & 1 & 0.912 & 0.880 & 0.887 & 0.725 \\
\hline & 2 & 0.862 & & & \\
\hline & 3 & 0.775 & & & \\
\hline \multirow[t]{3}{*}{ Satisfaction } & 1 & 0.925 & 0.940 & 0.942 & 0.843 \\
\hline & 2 & 0.944 & & & \\
\hline & 3 & 0.885 & & & \\
\hline
\end{tabular}


Common theory uses various indexes to test the fit of the structural model, while the most frequently used indexes in the reviewed literature within the scope of this research can be listed as $\lambda^{2} / \mathrm{df}$ (df: degrees of freedom), TLI, NFI, CFI, RMSEA and SRMR. Fit index results of the proposed model are presented in Table 5; it shows that the measurement model has a satisfactory level of fit. In the literature, it is stated that $\lambda^{2} / \mathrm{df}$ should be lower than 3 for good fitting models (Owen, 2011). However, especially in large samples, $\lambda^{2} / \mathrm{df}$ value to be less than 4 is considered sufficient (Adornetto, Hensdiek, Meyer, In-Albon, Federer, \& Schneider 2008).925 students participated in the study and the study has a large sampling. Therefore, $\lambda^{2} /$ $\mathrm{df}$ value, 3.773 is at least acceptable.

To identify a factor model, at least three items are required per factor (Brown, 2014). However, most of the items in the literature measuring the Subjective Norm factor are not suitable to use for DLS. For this reason, in many studies in the distance learning literature, researchers measured the Subjective Norm factor with two items (Abbad, Morris, \& Nahlik, 2009, Chang, Hajiyev, \& Su, 2017, Davis \& Wong, 2007, Lee, 2006, Park, Son, \& Kim, 2012.b, Raaij \& Schepers, 2008, Song \& Kong, 2017, Yuen \& Ma 2008). In the study, the Subjective Norm factor is measured with two items in order to ensure that the items are suitable for the subject and the participants are able to evaluate them properly.

Table 5. Model Fit Results

\begin{tabular}{lccc}
\hline Fit Indices & Model & Recommended Values & References \\
\hline / df & 3.773 & $\leq 4-5$ & Schumacker and Lomax (2004) \\
TLI & 0.941 & $>0.90$ & Hu and Bentler (1999) \\
NFI & 0.931 & $>0.90$ & Bollen (1989) \\
CFI & 0.948 & $>0.90$ & Corrigan et al. (2001) \\
RMSEA & 0.055 & $<0.08$ & Jarvenpaa et al. (2000) \\
SRMR & 0.0582 & $<0.08$ & Hu and Bentler (1999) \\
\hline
\end{tabular}

\section{FINDINGS}

Interaction $(\beta=0.108, \mathrm{p}<0.001)$, Compatibility $(\beta=0.167, \mathrm{p}=0.001)$ and Time Effectiveness $(\beta=0.355, \mathrm{p}$ $<0.001$ ) were found out a significant and positive impact on Perceived Usefulness (Figure 3). Nevertheless, no significant relationship was found between Self Efficacy $(\beta=-0.041, p=0.051)$, Subjective Norm $(\beta=$ $-0.011, p=0.584)$, Enjoyment $(\beta=0.021, p=0.595)$, Perceived Ease of Use $(\beta=-0.041, p=0.101)$ and Perceived Usefulness. In conclusion, Hypotheses 5, 9 and 11 accepted while 1, 3, 7 and 15 rejected. In addition, Self Efficacy $(\beta=0.319, \mathrm{p}<0.001)$, Interaction $(\beta=0.134, \mathrm{p}=0.01)$ and Time Effectiveness $(\beta=0.355, p<0.001)$ are inferred to have a significant and positive relationship with Perceived Ease of Use while Anxiety $(\beta=-0.081, p=0.027)$ has a negative and significant relationship with this belief structure. However, no significant relationship between Subjective Norm $(\beta=-0.045, p=0.2)$, Enjoyment $(\beta=0.000$, $\mathrm{p}=0.996)$ and Perceived Ease of Use could be found. Hence, Hypotheses 2, 6, 10 and 12 were accepted while 4 and 8 rejected. Both Perceived Usefulness $(\beta=0.646, p<0.001)$ and Perceived Ease of Use $(\beta=$ $0.349, \mathrm{p}<0.001)$ were detected to have a significant and positive influence on user satisfaction, while a significant correlation between Satisfaction and Intention to Use was also observed $(\beta=0.857, p<0.001)$, leading to the accepted of Hypotheses 13,14 and 16.

The direct and indirect effects of the independent variables on the dependent variables are given in Appendix B. Considering the total effect, The most effective variables on Perceived Usefulness are the exogenous variables Time Effectiveness and Compatibility, on Perceived Ease of Use are the exogenous variables Time Effectiveness and Self Efficacy, on Satisfaction and Intention are the exogenous variables Time Effectiveness and Interaction, respectively. Independent variables introduced explain $38.2 \%$ and $83.3 \%$ of Perceived Ease of Use and Perceived Usefulness, respectively; while they uncover 73\% of User Satisfaction and $73.5 \%$ of Intention to Use. 


\section{DISCUSSIONS AND CONCLUSION}

This study analyses the impact of various explanatory variables on students' satisfaction on and intention to use DLS through Perceived Usefulness and Perceived Ease of Use. Therefore, a model that is based on Technology Acceptance Model is developed and empirically tested. Results of these assessments are summarized below:

First, the outcomes of the tests conducted show that Time Effectiveness, Compatibility and Interaction have a significant impact on Perceived Usefulness. Thus, students' expectation that they will achieve a high learning output while spending a short time in the system (Time Effectiveness) will increase their perception of finding the system useful. The strong correlation between time and usefulness is anticipated for generation $\mathrm{z}$, a generation characterized by fast consumption. Moreover, the learners' opinions that the system is suited to their current values, needs and experiences (Compatibility) have a positive effect on the system being deemed as beneficial. It is likely that a student who has undergone through getting education via a digital platform for the first time may find that process to be inharmonious with her previous experiences. Nevertheless, it should also be stated that the student will deem the experience similar to watching instructive videos online to find solutions to everyday problems. In addition, system's enabling of effective and rapid communication between instructors and pupils (Interaction) have an effect on the perception regarding advantageousness. For instance, upon receiving feedback after asking a question about the course or voicing a concern regarding the classes, a student is more probable to think that the system will enhance her performance.

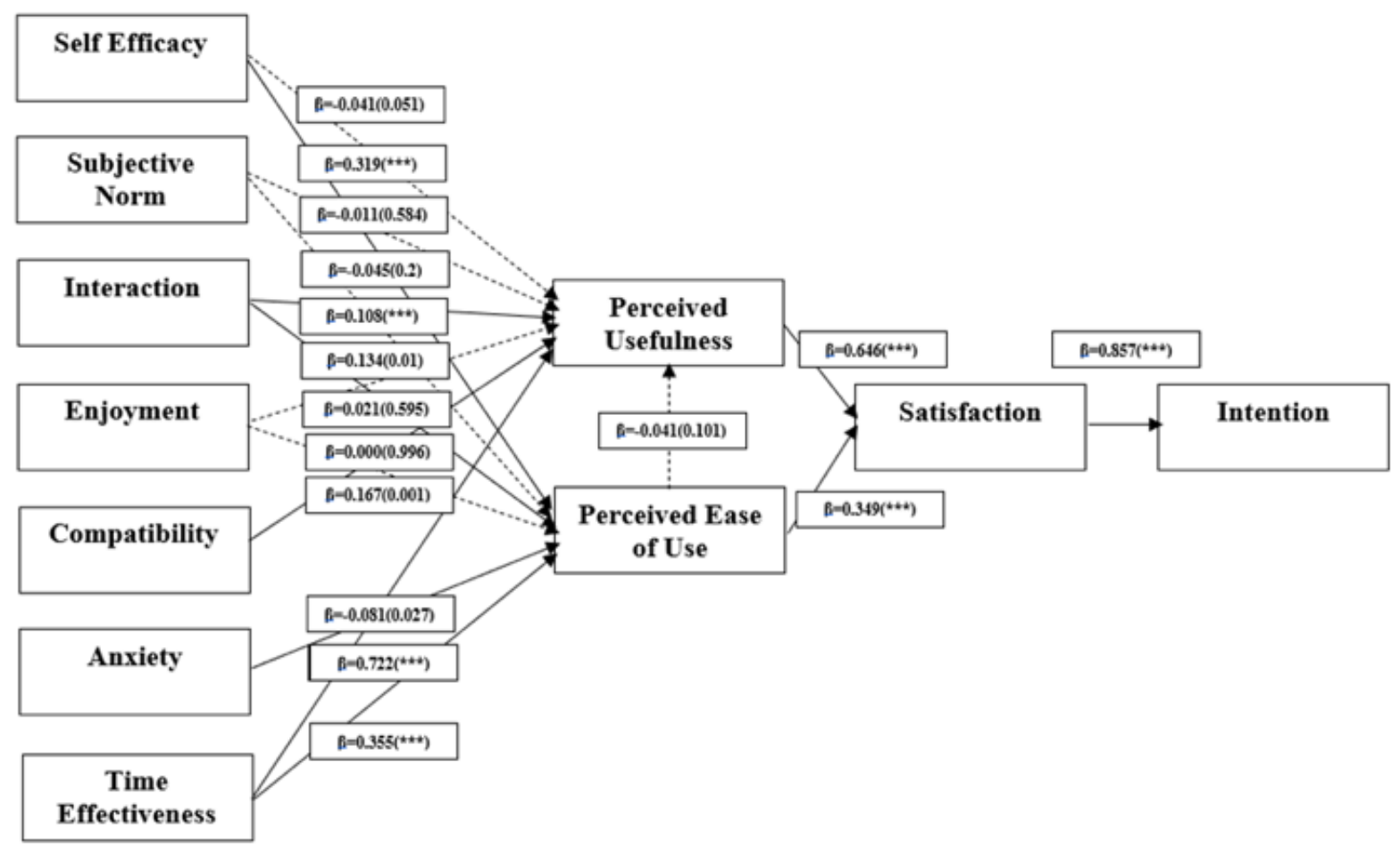

Figure 3. Results of Hypothesis Testing

Note: $\mathrm{n}=925$, The $\mathrm{p}$ values are presented in the parentheses, ${ }^{\text {****' }}$ meaning $\mathrm{p}<0.001$

First, the outcomes of the tests conducted show that Time Effectiveness, Compatibility and Interaction have a significant impact on Perceived Usefulness. Thus, students' expectation that they will achieve a high learning output while spending a short time in the system (Time Effectiveness) will increase their perception of finding the system useful. The strong correlation between time and usefulness is anticipated for generationz, a generation characterized by fast consumption. Moreover, the learners' opinions that the system is suited to 
their current values, needs and experiences (Compatibility) have a positive effect on the system being deemed as beneficial. It is likely that a student who has undergone through getting education via a digital platform for the first time may find that process to be inharmonious with her previous experiences. Nevertheless, it should also be stated that the student will deem the experience similar to watching instructive videos online to find solutions to everyday problems. In addition, system's enabling of effective and rapid communication between instructors and pupils (Interaction) have an effect on the perception regarding advantageousness. For instance, upon receiving feedback after asking a question about the course or voicing a concern regarding the classes, a student is more probable to think that the system will enhance her performance.

Second, according to our findings, Time Effectiveness, Self Efficacy, Interaction and Anxiety have a significant effect on Perceived Ease of Use. If a user worries that no significant return is gotten for time spent using DLS (Time Effectiveness), she will think that extra effort would be showed for utilizing the system and possibly shy away from doing so. Moreover, students' self-confidence in undertaking certain tasks during systems usage (Self Efficacy) has a positive influence on the perception regarding system's user-friendliness. An individual who is confident about her skills on technology is likely believe that she can overcome any obstacles upon utilizing DLS. In addition, rapid and effective communication between users (Interaction) has a positive impact on Perceived Ease of Use. If problems encountered while utilizing the system are shared with peers and instructors, will facilitate the resolution of the issue and ease the usage. Last, inclination of the learners to feel uncomfortable, worried and stressed about the current and/or potential utilization of the system (Anxiety) bears negative implications on ease of use. Thus, if a student feels worried while utilizing DLS, she might agonize that potential problems upon usage may not be resolved and hence, the system may not be user-friendly.

Thirdly, in this study Satisfaction was tested both as a dependent and independent variable. Despite being one of the most frequently used antecedents of information technology success (De Lone \& Mc Lean, 1992), Satisfaction is not included in Technology Acceptance Model. Previous research based on the aforementioned theory that incorporates Satisfaction into their respective models are reviewed during this study, and in light of those, the variable is decided to be embedded into the model. Results show that both Perceived Usefulness and Perceived Ease of Use have a positive and significant impact on User Satisfaction. It can be inferred that users are pleased with systems that facilitate their academic performance without sparing any additional effort. Likewise, satisfaction is a robust determinant of intention to use. The results show that identifying and assessing the factors that influence student satisfaction bear a vital role in DLS success.

Lastly, model proposed in this study is tested in 9 different state universities based in Turkey, where the results put forward a high degree of explanatory power for User Satisfaction and Intention to Use. If one pays special attention to investments made in distance learning in Turkey and the number of users utilizing those systems, the materiality of these outcomes is magnified. Moreover, the distance learning market is growing rapidly in the Middle East, as Turkey and Egypt are the two biggest customers in the region (Docebo, 2016). In many universities, several courses such as foreign language are taught through this medium (Kirkan \& Kalelioglu, 2017). Nevertheless, the fact that these systems are newly implemented leads to adaptation problems for both instructors and students (Duzakin \& Yalcinkaya, 2008). All in all, this research aims to yield benefits for system designers, instructors and educational institutions to pursue their objective of widespread, active and motivated usage of DLS.

\section{Contributions and Implications}

In this part of the study, based on the findings obtained as a result of the analysis, inferences that can be used by instructor, system developers and system designers are presented. It can be stated that instructors and educational institutions can reach a wider span of students with relatively lower costs through DLS. For this reason, they should strive to increase users' intention to use via modifying the system before, during and after utilization. In the study, it was seen that the external variable that had the greatest effect on belief variables was the Time Effectiveness variable. For example, educational institutions can convince users that they will 
achieve a great output in a very short time thanks to DLS with a promotion they will make at the beginning of the semester. Instructors, on the other hand, can tell students how effective the system is in terms of time with the announcements they make during the semester. Self Efficacy is another variable that has an effect on system usage. With the training videos to be prepared, students can be guided on how to use the system and thus their confidence in using DLS can be increased. Educational institutions can communicate with system designers to create platforms that will enable students to interact healthily among themselves and with their instructors. For example, users can communicate with each other effectively through forum discussion platforms and video conferencing tools. Moreover, instructors should answer questions posed by students quickly and explicitly. In addition, senior management can reduce the anxiety of both instructors and students with the institutional support.

Systems developers and designers should transform DLS into being more user-friendly and functional so that a more positive attitude towards the system is established and the benefits upon utilizing DLS is more easily reaped. Positive attitudes towards system use can be created with innovations to be developed. Therefore, they should focus on the variables that are observed to strongly affect the intention to use. For example, if they purify the system from unnecessary complexities and make it user-friendly, students' anxiety will decrease and their self-confidence in using the system will increase. It should be ensured that students do not spend too much time watching the lecture videos and accessing the lecture notes shared by the instructor. Thus, they are convinced that they will achieve a high output in a short time through the system. Designers should demonstrate that the use of the system does not require an advanced knowledge of computers and technology, and that the system is not incompatible with the current values and needs of the users. In addition, the system should be designed in a way that users can easily communicate with each other.

\section{Limitation and Suggestions}

Even though the model proposed in this study have significant implications for researchers and systems developers, some limitations are prevalent. First, the perceptions of users are calculated within only one, and a certain time frame; as students' opinions on ease of use and usefulness can change within time with new information and experience.

In the study, the effects of seven external variables on belief structures were tested. In future studies, new and original variables can be added to the model and their effects on Perceived Usefulness and Perceived Ease of Use can be observed.

As a result of the widespread use of internet, advances in information technologies, and economic developments in developing countries, DLS have been used in many different regions (Baki, Aktepe, \& Birgoren, 2019). Especially Middle Eastern countries are investing in DLS to change their dependencies on their natural resourced based economies and foreign labour force (Docebo, 2016). Therefore, the model proposed in this research should be tested for various countries, particularly for the ones in the Middle East. The model is expected to maintain its effectiveness in different regions and cultures.

Testing the model for different user types and varying information technologies to compare and cross-check the theory can also be of an added value, as the effects of the pre-determinants may vary across users and technologies.

The study accepts that Time Effectiveness has a robust effect on belief structures. Yet it should be stated that the survey respondents are using DLS for taking elective courses that have less credit and are not directly related to their majors. It is likely that when students use DLS for taking lessons that are deemed to bear more significance for their careers, they will attribute less importance to the time spent using the system, so the magnitude of the effect will be lessened. Therefore, testing Time Effectiveness for varying distance learning platforms will prove valuable for the literature. 


\section{BIODATA AND CONTACT ADDRESSES OF AUTHORS}

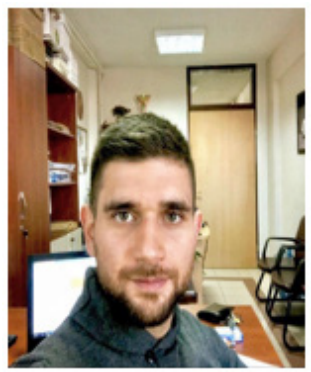

Dr. Rahmi BAKI is an Assistant Professor Doctor in the Department of Management Information Systems at Aksaray University, Turkey. Dr. Baki has received the BSc degree in industrial engineering from Gazi University in 2011, MSc degree in industrial engineering from Gazi University in 2014 and PhD degree from Kirikkale University Industrial Engineering Department in 2019. His academic interest areas are multi criteria decision making, fuzzy logic, structural equation modeling, supply chain management and distance education.

Rahmi BAKI

Department of Management Information Systems, Faculty of Economics and Administrative Sciences Address: Aksaray University, 68100, Aksaray, Turkey

Phone: + 903822882458

E-mail: rahmibaki@aksaray.edu.tr

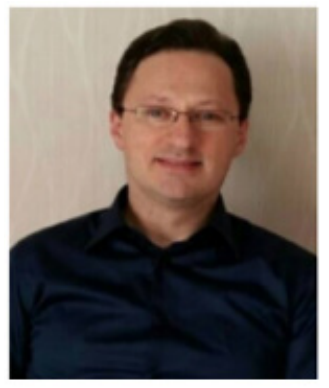

Dr. Burak BIRGOREN is a Professor of Industrial Engineering at Faculty of Engineering and Architecture, Kirikkale University. Dr. Birgoren gained his Ph.D. in Industrial Engineering at PennState University in 1998. His academic interest areas are quality control and management, reliability engineering, production planning and control.

Burak BIRGOREN

Department of Industrial Engineering Faculty of Engineering and Architecture Address: Kirikkale University, 71451, Kirikkale, Turkey

Phone: + 90318357 4242/1010

E-mail: birgoren@kku.edu.tr

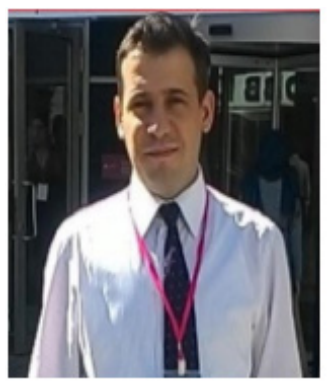

Dr. Adnan AKTEPE is an Associate Professor in the Department of Industrial Engineering at Kirikkale University, Turkey. He has received the BSc degree in industrial engineering from Marmara University in 2007; MSc degree in industrial engineering from Kirikkale University in 2011 and $\mathrm{PhD}$ degree from Gazi University Industrial Engineering Department in 2015. His research areas include performance management, customer satisfaction, applications of multi-criteria decision making methods, fuzzy logic, data mining, service systems and intelligent techniques in industrial engineering and management science.

Adnan AKTEPE

Department of Industrial Engineering Faculty of Engineering and Architecture

Address: Kirikkale University, 71451, Kirikkale, Turkey

Phone: +903183574242/1009

E-mail: aaktepe@gmail.com 


\section{REFERENCES}

Abbad, M. M., Morris, D., \& Nahlik, C. D. (2009). Looking under the bonnet: Factors affecting student adoption of e-Learning systems in Jordan. International Review of Research in Open and Distance Learning, 10(2), 1-15.

Abdullah, F., \& Ward, R. (2016). Developing a general extended technology acceptance model dor e-learning (GETAMEL) by analysing commonly used external factors. Computers in Human Behaviour, 56, 238-256.

Abdullah, F., Ward, R., \& Ahmed, E. (2016). Investigating the influence of the most commonly used external variables of TAM on students' perceived ease of use (PEOU) and perceived usefulness (PU) of e-portfolios. Computers in Human Behavior, 63, 75-90.

Abramson, J., Dawson, M., \& Stevens, J. (2015). An examination of the prior use of e-learning within an extended technology acceptance model and the factors that influence the behavioral intention of users to use m-learning. SAGE Open, 5(4), 1-9.

Adornetto, C., Hensdiek, M., Meyer, A., In-Albon, T., Federer, M., \& Schneider, S. (2008). The factor structure of the childhood anxiety sensitivity index in German children. Journal of Behavior Therapy and Experimental Psychiatry, 39(4), 404-416.

Agudo-Peregrina, A. F., Hernandez-Garcia, A., \& Pascual-Miguel, F. J. (2014). Behavioral intention, use behavior and the acceptance of electronic learning systems: Differences between higher education and lifelong learning. Computers in Human Behavior, 34, 301-314.

Ajzen, I. (1991). The theory of planned behaviour. Organizational Behavior and Human Decision Processes, 50(2), 179-211.

Al-Ammari, J., \& Hamad, S. (2008, April). Factors influencing the adoption of e-learning at UOB. In 2nd International Conference and Exhibition for Zain E-learning Center, 28-30.

Al-Ammary, J. H., Al-Sherooqi, A. K., \& Al-Sherooqi, H. K. (2014). The acceptance of social networking as a learning tools at University of Bahrain. International Journal of Information and Education Technology, 4(2), 208.

Al-Aulamie, A., Mansour, A., Daly, H., \& Adjei, O. (2012, June). The effect of interinsic motivation on learners' behavioural intention to use e-learning systems. In 2012 International Conference on Information Technology Based Higher Education and Training (ITHET), 1-4.

Al-Azawei, A., \& Lundqvist, K. (2015). Learner Differences in Perceived Satisfaction of an Online Learning: An Extension to the Technology Acceptance Model in an Arabic Sample. Electronic Journal of e-Learning, 13(5), 408-426.

Al-Azawei, A., Parslow, P., \& Lundqvist, K. (2017). Investigating the effect of learning styles in a blended e-learning system: An extension of the technology acceptance model (TAM). Australasian Journal of Educational Technology, 33(2), 1-23.

Al-Gahtani, S. S. (2016). Empirical investigation of e-learning acceptance and assimilation: A structural equation model. Applied Computing and Informatics, 12(1), 27-50.

Al-Hawari, M. A., \& Mouakket, S. (2010). The influence of technology acceptance model (tam) factors on students'e-satisfaction and e-retention within the context of uae e-learning. Education, Business and Society: Contemporary Middle Eastern Issues, 3(4), 299-314.

Ali, H., Ahmed, A. A., Tariq, T. G., \& Safdar, H. (2013, May). Second Life (SL) in Education: the intensions to use at university of bahrain. In 2013 Fourth International Conference on e-Learning" Best Practices in Management, Design and Development of e-Courses: Standards of Excellence and Creativity, 205-215.

Al-Mushasha, N. F. A. (2013, May). Determinants of e-learning acceptance in higher education environment based on extended technology acceptance model. In 2013 Fourth International Conference on e-Learning, 261-266. 
Al-Rahmi, W. M., Yahaya, N., Alamri, M. M., Alyoussef, I. Y., Al-Rahmi, A. M., \& Kamin, Y. B. (2019.a). Integrating innovation diffusion theory with technology acceptance model: supporting students' attitude towards using a massive open online courses (MOOCs) systems. Interactive Learning Environments, 1-13.

Al-Rahmi, W. M., Yahaya, N., Aldraiweesh, A. A., Alamri, M. M., Aljarboa, N. A., Alturki, U., \& Aljeraiwi, A. A. (2019.b). Integrating technology acceptance model with innovation diffusion theory: An empirical investigation on students' intention to use E-learning systems. IEEE Access, 7, 26797 26809.

Al-Sharafi, M. A., Mufadhal, M. E., Arshah, R. A., \& Sahabudin, N. A. (2019). Acceptance of online social networks as technology-based education tools among higher institution students: Structural equation modeling approach. Scientia Iranica, 26, 136-144.

Althunibat, A. (2015). Determining the factors influencing students' intention to use m-learning in Jordan higher education. Computers in Human Behavior, 52, 65-71.

Arenas-Gaitan, J., Rondan-Cataluña, F. J., \& Ramirez-Correa, P. E. (2010, November). Gender influence in perception and adoption of e-learning platforms. In Proceedings of the 9th WSEAS international conference on Data networks, communications, computersi, 30-35.

Armenteros, M., Liaw, S. S., Fernandez, M., Diaz, R. F., \& Sanchez, R. A. (2013). Surveying FIFA instructors' behavioral intention toward the Multimedia Teaching Materials. Computers \& Education, 61, 91-104.

Aypay, A., Celik, H. C., Aypay, A., \& Sever, M. (2012). Technology Acceptance in Education: A Study of Pre-Service Teachers in Turkey. Turkish Online Journal of Educational Technology-TOJET, 11(4), 264-272.

Baharin, A.T., Lateh, H., Nathan, S. S., \& Nawawi, H. M. (2015). Evaluating effectiveness of IDEWL using technology acceptance model. Procedia - Social and Behavioral Sciences, 171, 897-904.

Baki, R., Aktepe, A., \& Birgoren, B. (2019). Factors affecting the acceptance of e-learning for users with respect to user type, region, culture, welfare and development levels. MANAS Journal of Social Studies, 8(2), 2214-2242.

Baki, R., Birgoren, B., \& Aktepe, A. (2018). A meta analysis of factors affecting perceived usefulness and perceived ease of use in the adoption of e-learning systems. Turkish Online Journal of Distance Education, 19(4), 4-42.

Bandura, A., (1982). Self-efficacy mechanism in human agency. American Psychologist, 37(2), 122-147.

Basoglu, N., \& Ozdogan, K. (2015). Exploring the Major Determinants of Mobile Learning Adoption. Bogazici University Journal of Education, 28(1), 31-46.

Binyamin, S. S., Rutter, M. J., \& Smith, S. (2019). Extending the Technology Acceptance Model to Understand Students' use of Learning Management Systems in Saudi Higher Education. International Journal of Emerging Technologies in Learning, 14(3).

Bhatiasevi, V. (2011). Acceptance of e-learning for users in higher education: An extension of the technology acceptance model. The Social Sciences, 6(6): 513-520.

Bollen, K. A. (1989). A new incremental fit index for general structural equation models. Sociological Methods \& Research, 17(3), 303-316.

Brown, T. A. (2014). Confirmatory factor analysis for applied research. New York, NY: Guilford Publications.

Brown, I., Stothers, R., Thorp, S., \& Ingram, L. (2006, June). The role of learning styles in the acceptance of web-based learning tools. In 36th Annual Conference of the Southern African Computer Lecturers Association SACLA2006, 189-200.

Chang, C. T., Hajiyev, J., \& Su, C. R. (2017). Examining the students' behavioral intention to use elearning in Azerbaijan? The general extended technology acceptance model for e-learning approach. Computers \& Education, 111, 128-143. 
Chang, Y. H., \& Liu, J. C. (2013). Applying an AR technique to enhance situated heritage learning in a ubiquiious learning environment. The Turkish Online Journal of Educational Technology, 12(3), $21-32$.

Chang, S. C., \& Tung, F. C. (2008). An empirical investigation of students' behavioural intentions to use the online learning course websites. British Journal of Educational Technology, 39(1), 71-83.

Chen, Y. C., Lin, Y. C., Yeh, R. C., \& Lou, S.J. (2013). Examining factors affecting college students' intention to use web-based instruction systems: Towards an integrated model. Turkish Online Journal of Educational Technology, 12(2), 111-121.

Chen, H. R., \& Tseng, H. F. (2012). Factors that influence acceptance of web-based e-learning systems for the in-service education of junior high school teachers in Taiwan. Evaluation and Program Planning, 35(3), 398-406.

Chen, N. S., Wei, C. W., \& Chen, H. J. (2008). Mining e-Learning domain concept map from academic articles. Computers \& Education, 50(3), 1009-1021.

Cheng, Y. M. (2011). Antecedents and consequences of e-learning acceptance. Information Systems Journal, 21(3), 269-299, 2011.

Cheng, Y.M. (2012). Effects of quality antecedents on e-learning acceptance. Internet Research, 22(3), 361390.

Cheng, Y. M. (2013). Exploring the roles of interaction and flow in explaining nurses'e-learning acceptance. Nurse education today, 33(1), 73-80.

Cheng, Y. M. (2015). Towards an understanding of the factors affecting m-learning acceptance: Roles of technological characteristics and compatibility. Asia Pacific Management Review, 20(3), 109-119.

Cheng, Y. M. (2019). How does task-technology fit influence cloud-based e-learning continuance and impact?. Education+ Training, 61(4), 480-499.

Cho, V., Cheng, T. E., \& Lai, W. J. (2009.a). The role of perceived user-interface design in continued usage intention of self-paced e-learning tools. Computers \& Education, 53(2), 216-227.

Cho, V., Cheng, T. C. E., \& Hung, H. (2009.b). Continued usage of technology versus situational factors: An empirical analysis. Journal of Engineering and Technology Management, 26(4), 264-284.

Chow, M., Chan, L., Lo, B., Chu, W. P., Chan, T., \& Lai, Y. M. (2013). Exploring the intention to use a clinical imaging portal for enhancing healthcare education. Nurse education today, 33(6), 655662.

Chow, M., Herold, D. K., Choo, T. M., \& Chan, K. (2012). Extending the technology acceptance model to explore the intention to use Second Life for enhancing healthcare education. Computers \& Education, 59(4), 1136-1144.

Corrigan, P. W., Edwards, A. B., Green, A., Diwan, S. L., \& Penn, D. L. (2001). Prejudice, social distance, and familiarity with mental illness. Schizophrenia bulletin, 27(2), 219-225.

Calisir, F., Gumussoy, C.A., Bayraktaroglu, A. E., \& Karaali, D. (2014). Predicting the intention to use a web-based learning system: Perceived content quality, anxiety, perceived system quality, image, and the technology acceptance model. Human Factors and Ergonomics in Manufacturing \& Service Industries, 24(5), 515-531.

Cigdem, H., \& Topcu, A. (2015). Predictors of instructors' behavioral intention to use learning management system: A Turkish vocational college example. Computers in Human Behavior, 52, 22-28.

Coskuncay, F., \& Ozkan, S. (2013). A model for instructors» adoption of learning management systems: Empirical validation in higher education context. Turkish Online Journal of Educational Technology-TOJET, 12(2), 13-25.

Davis, F. D. (1989). Perceived usefulness, perceived ease of use, and user acceptance of information technology. MIS Quarterly, 13(3), 319-340. 
Davis, F. D., Bagozzi, R. P., \& Warshaw, P. R. (1989). User acceptance of computer technology: A comparison of two theoretical models. Management Science, 35(8), 982-1003.

Davis, R., \& Wong, D. (2007). Conceptualizing and measuring the optimal experience of the e-learning environment. Decision Sciences Journal of Innovative Education, 5(1), 97-126.

De Lone, W. H., \& Mc Lean, E. R. (1992). Information systems success: The quest for the dependent variable. Information Systems Research, 3(1), 60-95.

De Smet, C., Bourgonjon, J., De Wever, B., Schellens, T., \& Valcke, M. (2012). Researching instructional use and the technology acceptation of learning management systems by secondary school teachers. Computers \& Education, 58(2), 688-696.

Docebo. (2016). E-Learning market trends and forecast 2017-2021. Retrieved from https://www.docebo. $\mathrm{com} /$ resource/elearning-market-trends-and-forecast-2017-2021/

Duzakin, E., \& Yalcinkaya, S. (2008). Web tabanli uzaktan egitim sistemi ve Cukurova Universitesi ogretim elemanlarinin yatkinliklari [Web based distance education system and the predispositions of Cukurova University instructors]. Journal of Cukurova University Institute of Social Sciences, 17(1).

Farahat, T. (2012). Applying the technology acceptance model to online learning in the Egyptian universities. Procedia - Social and Behavioral Sciences, 64, 95-104.

Fornell, C., \& Larcker, D. F. (1981). Evaluating structural equation models with unobservable variables and measurement error. Journal of Marketing Research, 18(1), 39-50.

George, D., \& Mallery, P. (2003). SPSS for Windows step by step: A simple guide and reference. Boston, Allyn \& Bacon.

Hair, J., Anderson, R., Tatham, R., \& Black, W. (1998). Multivariate data analysis. New Jersey, Prentice Hall.

Hair, J. F., Black, W. C., Babin, B. J., \& Anderson, R. E. (2010). Multivariate data analysis. New Jersey, Prentice Hall.

Heijden, H. V. D. (2003). Factors influencing the usage of websites: The case of a generic portal in The Netherlands. Information \& Management, 40(6), 541-549.

Hsia, J. W., Chang, C. C., \& Tseng, A. H. (2014). Effects of individuals' locus of control and computer self-efficacy on their e-learning acceptance in high-tech companies. Behaviour \& Information Technology, 33(1), 51-64.

Hsia, J. W., Chen, C. A., Chiang, Y. H., Hsu, T. K., \& Tseng, A. H. (2018). The role of internet self-efficacy in the acceptance of an educational portal. International Journal of Organizational Innovation, $11(2), 350-358$

Hsiao, K. L., \& Chen, C. C. (2015). How do we inspire children to learn with e-readers?. Library Hi Tech, 33(4), 584-596.

Hu, L. T., \& Bentler, P. M. (1999). Cutoff criteria for fit indexes in covariance structure analysis: Conventional criteria versus new alternatives. Structural Equation Modeling: A Multidisciplinary Journal, 6(1), $1-55$.

Huang, J. H., Lin, Y. R., \& Chuang, S. T. (2007). Elucidating user behavior of mobile learning: A perspective of the extended technology acceptance model. The Electronic Library, 25(5), 585-598.

Hussein, R., Aditiawarman, U., \& Mohamed, N. (2007, May). E-learning acceptance in a developing country: A case of the Indonesian Open University. In German e-Science conference, 1-14.

Igbaria, M., \& Parasuraman, S. (1989). A path analytic study of individual characteristics, computer anxiety and attitudes toward microcomputers. Journal of Management, 15(3), 373-388.

Jarvenpaa, S. L., Tractinsky, N., \& Vitale, M. (2000). Consumer trust in an Internet store. Information Technology and Management, 1(1-2), 45-71. 
Joo, Y. J., So, H. J., \& Kim, N. H. (2018). Examination of relationships among students' self-determination, technology acceptance, satisfaction, and continuance intention to use K-MOOCs. Computers \& Education, 122, 260-272.

Jung, H. J. (2015). Fostering an English teaching environment: Factors influencing English as a foreign language teachers' adoption of mobile learning. Informatics in Education-An International Journal, 14(2), 219-241.

Kang, M., \& Shin, W. S. (2015). Investigation of student acceptance of synchronous e-learning in an online university. Journal of Educational Computing Research, 52(4), 475-495.

Karaali, D., Gumussoy, C. A., \& Calisir, F. (2011). Factors affecting the intention to use a web-based learning system among blue-collar workers in the automotive industry. Computers in Human Behavior, 27(1), 343-354.

Kilic, E., Guler, C., Celik, H. E., \& Tatli, C. (2015). Learning with interactive whiteboards: Determining the factors on promoting interactive whiteboards to students by Technology Acceptance Model. Interactive Technology and Smart Education, 12(4), 285-297.

Kirkan, B., \& Kalelioglu, F. (2017). Turkiye'de uzaktan egitim merkezlerinin durumu: Betimsel bir calisma [Status of distance education centers in Turkey: A descriptive study]. Journal of Instructional Technologies \& Teacher Education Vol, 6(3), 88-98.

Kimathi, F. A., \& Zhang, Y. (2019). Exploring the general extended technology acceptance model for e-learning approach on student's usage intention on e-learning system in University of Dar es Salaam. Creative Education, 10(01), 208.

Lai, J. Y., \& Ulhas, K.R. (2012). Understanding acceptance of dedicated e-textbook applications for learning: Involving Taiwanese university students. The Electronic Library, 30(3), 321-338.

Lee, Y. C. (2006). An empirical investigation into factors influencing the adoption of an e-learning system. Online Information Review, 30(5), 517-541.

Lee, M. C. (2010). Explaining and predicting users' continuance intention toward e-learning: An extension of the expectation-confirmation model. Computers \& Education, 54(2), 506-516.

Lee, Y. H., Hsiao, C., \& Purnomo, S. H. (2014). An empirical examination of individual and system characteristics on enhancing e-learning acceptance. Australasian Journal of Educational Technology, $30(5)$.

Lee, Y. H., Hsieh, Y. C., \& Chen, Y. H. (2013). An investigation of employees' use of e-learning systems: applying the technology acceptance model. Behaviour \& Information Technology, 32(2), 173189.

Lee, Y. H., Hsieh, Y. C., \& Hsu, C. N. (2011.a). Adding innovation diffusion theory to the technology acceptance model: Supporting employees' intentions to use e-learning systems. Journal of Educational Technology \& Society, 14(4), 124-137.

Lee, Y. H., Hsieh, Y. C., \& Ma, C. Y. (2011.b). A model of organizational employees'e-learning systems acceptance. Knowledge-based systems, 24(3), 355-366.

Lee, D. Y., \& Lehto, M. R. (2013). User acceptance of YouTube for procedural learning: An extension of the Technology Acceptance Model. Computers \& Education, 61, 193-208.

Lefievre, V. (2012-May). Gender differences in acceptance by students of training software for office tools, 14th Annual International Conference on Education, 1-13.

Legris, P., Ingham, J., \& Collerette, P. (2003). Why do people use information technology? A critical review of the technology acceptance model. Information \& Management, 40(3), 191-204.

Li, Y., Duan, Y., Fu, Z., \& Alford, P. (2012). An empirical study on behavioural intention to reuse e-learning systems in rural China. British Journal of Educational Technology, 43(6), 933-948.

Liao, L. F. (2006). A flow theory perspective on learner motivation and behavior in distance education. Distance Education, 27(1), 45-62. 
Lin, Y. C., Chen, Y. C., \& Yeh, R. C. (2010). Understanding college students' continuing intentions to use multimedia e learning systems. World Transactions on Engineering and Technology Education, $8(4), 488-493$.

Lin, S. C., Persada, S. F., \& Nadlifatin, R. (2014, May). A study of student behavior in accepting the Blackboard Learning System: A Technology Acceptance Model (TAM) approach. In Proceedings of the 2014 IEEE 18th international conference on computer supported cooperative work in design (CSCWD), 457-462.

Liu, X. (2010). Empirical testing of a theoretical extension of the technology acceptance model: An exploratory study of educational wikis. Communication Education, 59(1), 52-69.

Liu, Z., \& Wei, Z. (2019, January). Research on Chinese College Students' Using Behavior towards E-learning Services Based on Improved TAM Model. In 2nd International Conference on Social Science, Public Health and Education (SSPHE 2018). Atlantis Press.

Lubbe, B., \& Louw, L. (2010). The perceived value of mobile devices to passengers across the airline travel activity chain. Journal of Air Transport Management, 16(1), 12-15.

Ma, C. M., Chao, C. M., \& Cheng, B. W. (2013). Integrating technology acceptance model and tasktechnology fit into blended E-learning system. Journal of Applied Sciences, 13(5), 736-742.

Martin, R. G. (2012). Factors affecting the usefulness of social networking inE-learning at German University of Technology in Oman. International Journal of e-Education, e-Business, e-Management and e-Learning, 2(6), 498-502.

Martinez-Torres, M. R., Marin, S. L. T., Garcia, F. B., Vazquez, S. G., Oliva, M. A., \& Torres, T. A. (2008). A technological acceptance of e-learning tools used in practical and laboratory teaching, according to the European higher education area. Behaviour \& Information Technology, 27(6), 495-505.

Mei, B., Brown, G. T., \& Teo, T. (2018). Toward an understanding of preservice English as a Foreign Language teachers' acceptance of computer-assisted language learning 2.0 in the People's Republic of China. Journal of Educational Computing Research, 56(1), 74-104.

Moghadam, A. H., \& Bairamzadeh, S. (2009, April). Extending the technology acceptance model for e-learning: A Case study of Iran. In 2009 Sixth International Conference on Information Technology: New Generations, 1659-1660.

Mohammadi, H. (2015.a). Investigating users' perspectives on e-learning: An integration of TAM and IS success model. Computers in Human Behavior, 45, 359-374.

Mohammadi, H. (2015.b). Factors affecting the e-learning outcomes: An integration of TAM and IS success model. Telematics and Informatics, 32(4), 701-719.

Moore, G. C., \& Benbasat, I. (1991). Development of an instrument to measure the perceptions of adopting an information technology innovation. Information Systems Research, 2(3), 192-222.

Motaghian, H., Hassanzadeh, A., \& Moghadam, D. K. (2013). Factors affecting university instructors' adoption of web-based learning systems: Case study of Iran. Computers \& Education, 61, 158-167.

Moreno, V., Cavazotte, F., \& Alves, I. (2017). Explaining university students' effective use of e-learning platforms. British Journal of Educational Technology, 48(4), 995-1009.

Nagy, J. T. (2018). Evaluation of online video usage and learning satisfaction: An extension of the technology acceptance model. The International Review of Research in Open and Distributed Learning, 19(1).

Olson, E. D., \& Brown, E. (2018). Perceptions of Students in an Event Management Program of Annotation Systems and Their Influence on Student Learning. Journal of Hospitality \& Tourism Education, 30(2), 118-126.

Ong, C. S., \& Lai, J. Y. (2006). Gender differences in perceptions and relationships among dominants of e-learning acceptance. Computers in human behavior, 22(5), 816-829.

Ong, C. S., Lai, J. Y., \& Wang, Y. S. (2004). Factors affecting engineers' acceptance of asynchronous e-learning systems in high-tech companies. Information \& management, 41(6), 795-804. 
Owen, J. (2011). Assessing the factor structures of the 55-and 22-item versions of the conformity to masculine norms inventory. American Journal of Men's Health, 5(2), 118-128.

Ozen, A., Altunoglu, B. K., \& Oztornaci, E. (2015). Orta ogretim duzeyindeki ogrencilerin vergi algilama duzeylerine iliskin ampirik bir degerlendirme [The empirical assesment of tax perception level of students at secondary school]. Journal of Management \& Economics, 22(2), 279-289.

Padilla-Melendez, A., Garrido-Moreno, A., \& Del Aguila-Obra, A. R. (2008). Factors affecting e-collaboration technology use among management students. Computers \& Education, 51(2), 609-623.

Park, S. Y. (2009). An analysis of the technology acceptance model in understanding university students' behavioral intention to use e-learning. Educational Technology \& Society, 12(3), 150-162.

Park, S. Y., Nam, M. W., \& Cha, S. B. (2012.a). University students' behavioral intention to use mobile learning: Evaluating the technology acceptance model. British Journal of Educational Technology, 43(4), 592-605.

Park, Y., Son, H., \& Kim, C. (2012.b). Investigating the determinants of construction professionals' acceptance of web-based training: an extension of the technology acceptance model. Automation in Construction, 22, 377-386.

Pituch, K. A., \& Lee, Y. K. (2006). The influence of system characteristics on e-learning use. Computers \& Education, 47(2), 222-244.

Post, S. W. (2010). Modeling of Stakeholders' Perceptions and Beliefs about e-Learning Technologies in Service-Learning Practices. Doctoral dissertation, TUI University. ProQuest LLC.

Punnoose, A. C. (2012). Determinants of intention to use eLearning based on the technology acceptance model. Journal of Information Technology Education: Research, 11(1), 301-337.

Purnomo, S. H., \& Lee, Y. H. (2013). E-learning adoption in the banking workplace in Indonesia: an empirical study. Information Development, 29(2), 138-153.

Raaij, E. M. V., \& Schepers, J. J. L. (2008). The acceptance and use of a virtual learning environment in China. Computers \& Education, 50(3), 838-852.

Ramayah, T., \& Lee, J. W. C. (2012). System characteristics, satisfaction and e-learning usage: a structural equation model (SEM). Turkish Online Journal of Educational Technology-TOJET, 11(2), 196-206.

Ramirez-Correa, P. E., Arenas-Gaitan, J., \& Rondan-Cataluña, F. J. (2015). Gender and acceptance of e-learning: a multi-group analysis based on a structural equation model among college students in Chile and Spain. PloS one, 10(10), 1-17.

Roca, J. C., Chiu, C. M., \& Martinez, F. J. (2006). Understanding e-learning continuance intention: An extension of the Technology Acceptance Model. International Journal of human-computer studies, 64(8), 683-696.

Saade, R.G., \& Kira, D. (2006). The emotional state of technology acceptance. Issues in Informing Science and Information Technology. 3: 529-539.

Schumacker, R. E., \& Lomax, R. G. (2004). A beginner's guide to structural equation modelingPsychology.

Shen, C. C., \& Chuang, H. M. (2010). Exploring users' attitudes and intentions toward the interactive whiteboard technology environment. International Review on Computers and Software, 5(2), 200-208.

Shen, J., \& Eder, L. B. (2009). Intentions to use virtual worlds for education. Journal of Information Systems Education, 20(2), 225.

Shih, B. Y., Chen, C. Y., Shih, C. H., \& Su, W. L. (2013). The control application and simulation-particle swarm optimization exploration of control application for user intention toward mobile Mandarin learning system. Journal of Vibration and Control, 19(13), 2036-2045.

Shyu, S. H. P., \& Huang, J. H. (2011). Elucidating usage of e-government learning: A perspective of the extended technology acceptance model. Government Information Quarterly, 28(4), 491-502, 2011. 
Song, Y., \& Kong, S. C. (2017). Investigating students' acceptance of a statistics learning platform using technology acceptance model. Journal of Educational Computing Research, 55(6), 865-897.

Sumak, B., Hericko, M., \& Pusnik, M. (2011). A meta-analysis of e-learning technology acceptance: The role of user types and e-learning technology types. Computers in Human Behavior, 27(6), 20672077.

Tung, F. C., \& Chang, S. C. (2008.a). Nursing students' behavioral intention to use online courses: A questionnaire survey. International Journal of Nursing Studies, 45(9), 1299-1309.

Tung, F. C., \& Chang, S. C. (2008.b). A new hybrid model for exploring the adoption of online nursing courses. Nurse Education Today. 28 (3): 293-300.

Tran, K. N. N. (2016). The Adoption of Blended E-learning Technology in Vietnam using a Revision of the Technology Acceptance Model. Journal of Information Technology Education, 15.

Tseng, A. H., \& Hsia, J. W. (2008, September). The impact of internal locus of control on perceived usefulness and perceived ease of use in e-learning: An extension of the technology acceptance model. In 2008 International Conference on Cyberworlds, 815-819.

Venkatesh, V., \& Bala., H. (2008). Technology acceptance model 3 and a research agenda on interventions. Decision Sciences, 39(2), 273-315.

Venkatesh, V., \& Davis, F. D. (2000). A theoretical extension of the technology acceptance model: Four longitudinal field studies. Management Science, 46(2), 186-204.

Vogel, P. (2015). Generation Jobless?: Turning the youth unemployment crisis into opportunity. London, Palgrave Macmillan.

Wang, W. T., \& Wang, C. C. (2009). An empirical study of instructor adoption of web-based learning systems. Computers \& Education, 53(3), 761-774.

Wu, B., \& Chen, X. (2017). Continuance intention to use MOOCs: Integrating the technology acceptance model (TAM) and task technology fit (TTF) model. Computers in Human Behavior, 67, 221232.

Wu, X., \& Gao, Y. (2011). Applying the extended technology acceptance model to the use of clickers in student learning: some evidence from macroeconomics classes. American Journal of Business Education, 4(7), 43-50.

Wu, C., Kuo, Y., \& Wu, S. (2013). Investigating the antecedents of university students' behavioral intention to use iPad for learning. International Journal of e-Education, e-Business, e-Management and e-Learning, 3(6), 468.

Yalcin, M.E., \& Kutlu, B. (2019). Examination of students' acceptance of and intention to use learning management systems using extended TAM. British Journal of Educational Technology.

Yang, S. C., \& Lin, C. H. (2011). Factors affecting the intention to use Facebook to support problem-based learning among employees in a Taiwanese manufacturing company. African Journal of Business Management, 5(22), 9014-9022.

Yi-Cheng, C., Chun-Yu, C., Yi-Chen, L., \& Ron-Chen, Y. (2007, July). Predicting College Student'Use of E-Learning Systems: An attempt to extend technology acceptance model. PACIS 2007 Proceedings, 172-183.

Yuen, A. H. K., \& Ma, W. W. K. (2008). Exploring teacher acceptance of e-learning technology. Asia-Pacific Journal of Teacher Education, 36(3), 229-243.

Zare, H., \& Yazdanparast, S. (2013). The causal Model of effective factors on intention to use of information technology among payamnoor and traditional universities students. Life Science Journal, 10(2), 46-50.

Zhang, N., Guo, X. H., \& Chen, G. Q. (2007). Extended information technology initial acceptance model and its empirical test. Systems Engineering-Theory \& Practice, 27(9), 123-130. 


\section{Appendix A}

Instrument

\begin{tabular}{|c|c|c|c|}
\hline Constructs & Item & Measures & References \\
\hline \multirow[t]{3}{*}{ Self Efficacy } & 1 & $\begin{array}{l}\text { I am confident of using the system even if there is no one around to } \\
\text { show me how to do it. }\end{array}$ & \multirow{3}{*}{$\begin{array}{c}\text { Abdullah et al. } \\
\text { (2016) }\end{array}$} \\
\hline & 2 & $\begin{array}{l}\text { I am confident of using the system even if I have never used such a } \\
\text { system before. }\end{array}$ & \\
\hline & 3 & $\begin{array}{c}\text { I am confident of using the system even if I have only a manual for } \\
\text { reference. }\end{array}$ & \\
\hline \multirow{2}{*}{$\begin{array}{l}\text { Subjective } \\
\text { Norm }\end{array}$} & 1 & People who influence my behaviour think that I should use the system. & \multirow{2}{*}{$\begin{array}{l}\text { Venkatesh and } \\
\text { Davis (2000) }\end{array}$} \\
\hline & 2 & People who are important to me think that I should use the system. & \\
\hline \multirow[t]{3}{*}{ Interaction } & 1 & $\begin{array}{l}\text { The system enables interactive communication between instructor and } \\
\text { students. }\end{array}$ & \multirow{3}{*}{$\begin{array}{l}\text { Pituch and Lee } \\
\text { (2006) }\end{array}$} \\
\hline & 2 & The system enables interactive communication among students. & \\
\hline & 3 & The communicational tools in the system are effective. & \\
\hline \multirow[t]{3}{*}{ Enjoyment } & 1 & I find using the system enjoyable. & \multirow{3}{*}{$\begin{array}{l}\text { Venkatesh and } \\
\text { Bala (2008) }\end{array}$} \\
\hline & 2 & The actual process of using the system is pleasant. & \\
\hline & 3 & I have fun using the system. & \\
\hline \multirow[t]{3}{*}{ Compatibility } & 1 & Using the system is compatible with most of my learning. & \multirow{3}{*}{$\begin{array}{c}\text { Tung and Chang } \\
\text { (2008.a) }\end{array}$} \\
\hline & 2 & Using the system is appropriate for my life style. & \\
\hline & 3 & Using the system is appropriate for my learning. & \\
\hline \multirow[t]{4}{*}{ Anxiety } & 1 & Computers do not scare me at all. & \multirow{4}{*}{$\begin{array}{l}\text { Venkatesh and } \\
\text { Bala (2008) }\end{array}$} \\
\hline & 2 & Working with a computer makes me nervous. & \\
\hline & 3 & Computers make me feel uncomfortable. & \\
\hline & 4 & Computers make me feel uneasy. & \\
\hline \multirow{3}{*}{$\begin{array}{l}\text { Time } \\
\text { Effectiveness }\end{array}$} & 1 & I am rewarded for the time I spent on system. & \multirow[t]{3}{*}{ Self developed } \\
\hline & 2 & $\begin{array}{c}\text { One hour I spend on the system is as efficient as an hour I take lessons in } \\
\text { class. }\end{array}$ & \\
\hline & 3 & I feel I have benefited from time spent within the system. & \\
\hline \multirow{4}{*}{$\begin{array}{l}\text { Perceived } \\
\text { Ease of Use }\end{array}$} & 1 & My interaction with the system is clear and understandable. & \multirow{4}{*}{$\begin{array}{l}\text { Venkatesh and } \\
\text { Bala (2008) }\end{array}$} \\
\hline & 2 & Interacting with the system does not require a lot of my mental effort. & \\
\hline & 3 & I find the system easy to use. & \\
\hline & 4 & I find it easy to get the system to do what I want it to do. & \\
\hline \multirow{4}{*}{$\begin{array}{l}\text { Perceived } \\
\text { Usefulness }\end{array}$} & 1 & Using the system improves my learning performance. & \multirow{4}{*}{$\begin{array}{l}\text { Venkatesh and } \\
\text { Bala (2008) }\end{array}$} \\
\hline & 2 & Using the system in learning increases my productivity. & \\
\hline & 3 & Using the system enhances my effectiveness in education. & \\
\hline & 4 & I find the system useful for my education. & \\
\hline \multirow[t]{3}{*}{ Intention } & 1 & Assuming I had access to the system, I intend to use it. & \multirow{3}{*}{$\begin{array}{l}\text { Venkatesh and } \\
\text { Bala (2008) }\end{array}$} \\
\hline & 2 & Given that I had access to the system, I predict that I would use it. & \\
\hline & 3 & I plan to use the system in future. & \\
\hline \multirow[t]{3}{*}{ Satisfaction } & 1 & I am satisfied with the performance of the system. & \multirow{3}{*}{$\begin{array}{l}\text { Roca et al. } \\
\text { (2006) }\end{array}$} \\
\hline & 2 & I am pleased with the experience of using the system. & \\
\hline & 3 & My decision to use the system was a wise one. & \\
\hline
\end{tabular}

